Archived version from NCDOCKS Institutional Repository http://libres.uncg.edu/ir/asu/

Schilbrack, Kevin. 2005. "Reading Hume's Dialogues: A Veneration For True Religion." Faith And

Philosophy 22, no. 3: 383-385. Published by Philosophy Documentation Center. (ISSN: 0739-7046)

[Review] (July 2005)

\title{
[A review of] Reading Hume's Dialogues: A Veneration for True Religion
}

\author{
Kevin Schilbrack
}

Reading Hume's Dialogues: A Veneration for True Religion by William Lad Sessions, Bloomington: Indiana University Press, 2002. Pp. X + 281. \$49.95 (cloth), \$24.95 (paper).

This is the first book length commentary on David Hume's Dialogues concerning Natural Religion. It is welcome in the first place simply because William Lad Sessions is a meticulous reader, and his observations are consistently insightful and profitable. But the approach of this book is distinctive, moreover, in that it pursues what Sessions calls an internal reading of the Dialogues. "External" interpretations use tools drawn from outside the text itself. They are external, for example, in that they address some contemporary philosophical question that was not Hume's, taking the form of what Sessions calls "mining operations" that extract pithy propositions or argumentative ore while ignoring the litera1y matrix from which they arise. Or they may be external in the sense that they read the Dialogues in terms of some other extratextual context, such as Hume's life and interests, or eighteenth- century intellectual movements, or the histo1y of skepticism. In contrast, Sessions pursues an internal reading that resolutely interprets the text on its own teems, tracing the connections between the individual parts of Hume's book and supposing (defeasibly) that the work forms a unity in which nothing is extraneous. By taking this approach, Sessions gives attention not only to the arguments made by the characters, but also to "seeing how what a character says connects with what he and other agents do, with how he speaks and acts, with the dramatic setting, personal relationships, and so on" (3). This is an approach, in other words, that takes the literary form of the dialogue seriously and refuses to reduce Hume's work to a list of arguments that might be put better by being less literary.

With this agenda, Sessions is careful and exhaustive. He not only comment on each individual paragraph of the Dialogues, but also pays attention to often overlooked parts such as the preface, the title, and the roles of Pamphilus and Hermippus. Sessions will even focus on a mentioned smile or on individual words or phrases. Here is an example. Noticing that the phrase "on a sudden" appears twice in the dialogues, Sessions points out that Philo once makes an 
announcement "on a sudden" but then later Cleanthes is unable to respond "on a sudden." "Here is the contrast between their characters in a nutshell: Philo rushes in where Cleanthes fears to tell" (245, n. 1). Sessions apparently sometimes fears that he is actually too attentive to detail, since he moves many speculations to footnotes and, at one spot, tells readers that they can jump ahead a few paragraphs if his point seems picayune.

Overall, Sessions is a judicious guide to the flow of the interaction between the characters. Perhaps he misfires only when he reads Demea's admittedly cross and obtuse contributions to the dialogues as "lashing out with threats," and then reads Philo and Cleanthes as ignoring Demea's "menace" (63-4). In this vein, Sessions claims that when Demea objects that Cleanthes' $s$ anthropomorphism is "dangerous," Demea at least implicitly means that it is dangerous to Demea and since he means to retaliate, this is "a clear threat to the one who threatens him" (89). Perhaps Sessions' strongest claim of this sort is that when Demea says that he prefers an a priori argument for God's existence because it "cuts off" doubt, Sessions sees malevolence in this choice of verb: "The martial and potentially violent connotations of 'cuts off' are significant and yield insight into Demea' s character. Demea is willing, should reason fail, to resort to threat and violence in support of what he regards as true religion" (249, n. 10). The threat of violence seems overstated, though this is not to deny that Sessions has Demea pegged exactly when he says that "Demea neither comprehends nor experiences equal friendship; all his personal relations are implicitly conflicts of will, struggles to control others or to resist their efforts at controlling him" and that "Demea's fearful natural religious piety issues in a coercive, hierarchical, authoritarian church that chiefly values 'submission and self-diffidence' in its members" $(228,223)$.

In my judgment, Sessions' internal reading, his focus on the literary form of the dialogues, brings two main benefits. First, it turns attention away from the legitimate but tired question of which of the characters represents Hume's mouthpiece. When one brackets this question, the dialogues appear much less didactic: they are instead an artful attempt to embody a living discussion on the issue of natural religion and thereby to stimulate thoughtful reflection in readers on how best to live it. As Sessions puts it, "Perhaps Hume genuinely thought that natural religion was so deeply perplexing, so ultimately unfathomable by human thought, that rather than enforcing his own views on the subject he chiefly wanted to stimulate thought on the part of his readers. Perhaps Hume wanted an intelligent reader not so much to agree or disagree with any of the characters as rather to think for herself about these hard subjects" (212). In this way, Sessions presents the "message" of the dialogues as more open-ended and more dialogical.

The second benefit of Sessions' approach is that, as Sessions makes clear, natural religion for Hume includes much more than the design argument--in fact, more than any set of beliefs. In the Dialogues, natural religion has both a theoretical and a practical dimension: it consists of both natural theology and natural piety, where the latter refers to the practices and attitudes of true religion. Here Philo and Cleanthes agree with each other, against Demea, for they agree that true piety permits an openness to inquiry and merely probable arguments. In this light, Sessions argues that Philo's reversal in Part 12 when he confesses his embrace of the design argument is explained best not as subterfuge or irony but rather as an honest confession of his beliefs, made possible by the exit in Part 11 of Demea and his authoritarian piety. Thus Philo does not dissemble when he and Cleanthes agree that true religion should "regulate the heart of men, regulate their conduct, infuse the spirit of temperance, order, and obedience." This shared sense of true piety is what brings Cleanthes and Philo together as friends and this is why true religion is something for which Philo-of all people--expresses veneration. 